Research Article

\title{
The Impact of Venture Capital Background on CEO Replacement in Portfolio Companies: Empirical Evidence from China
}

\author{
Haixia Hao $(1)$ and Lihong Guo \\ School of Economics and Management, Northwest University, Xi'an 710127, China \\ Correspondence should be addressed to Haixia Hao; 201910032@stumail.nwu.edu.cn
}

Received 31 August 2021; Accepted 29 November 2021; Published 22 December 2021

Academic Editor: Daqing Gong

Copyright $\odot 2021$ Haixia Hao and Lihong Guo. This is an open access article distributed under the Creative Commons Attribution License, which permits unrestricted use, distribution, and reproduction in any medium, provided the original work is properly cited.

\begin{abstract}
Taking Chinese startups backed by venture capital (VC) in 1997-2017 as the sample, this study investigates the impact of VC background on chief executive officer (CEO) replacement in portfolio companies. The results show that (1) compared to foreign VC, domestic VC is more likely to replace the CEO of the portfolio companies. (2) Syndicate with domestic VC can overcome the disadvantage of foreign VC geographically distant from the portfolio companies, and domestic VC as coinvestors can effectively monitor portfolio companies, increasing the possibility of CEO replacement. Heterogeneity analysis shows that the positive effect of VC background on CEO replacement exists in the subgroup of VC geographically proximate to the portfolio companies, indicating that geographic proximity to the portfolio companies helps VC more easily grasp the development of the portfolio companies and more likely to replace CEO. This paper reveals the differences in the behavior of VC in replacing CEO during the postinvestment management process, highlights the critical role of geographical proximity, and provides important management insights for VC and entrepreneurs.
\end{abstract}

\section{Introduction}

In recent years, venture capital (VC) has grown rapidly in China's capital market, and many startups have thrived with the power of $\mathrm{VC}$, while cases of chief executive officer (CEO) playing games with VC are frequently played out in VC circles. For example, Changjiang $\mathrm{Wu}, \mathrm{CEO}$ of Leishi Lighting; Zhidong Wang, CEO of Sina; and Yang Li, CEO of RedBaby, all left their companies because of disagreements with investors. In fact, startups with high growth potential often require two types of actors to develop: the CEO, who translates the idea into business practice, and the VC, who brings in financial resources [1], both of which work together to drive the growth of the startup. As the main body of corporate decision-making and execution, the CEO becomes a key factor in determining the success of the company; therefore, CEO replacement is bound to have an important impact on the development of the company [2].
Nowadays, academics have conducted research related to CEO replacement in VC-backed startups. Some scholars and practitioners have noted that driving CEO replacement in portfolio companies is a special mechanism for VC to improve company performance in the course of postinvestment management $[3,4]$. However, although the academic community has recognized that VC's support drives CEO replacement in portfolio companies, most studies so far have focused on exploring how CEO replacement affects the development of startups, and very little literature has examined the key issue of influencing CEO replacement from the perspective of the background of venture capital. With the increasing share of foreign VC entering the development of China's capital market, the similarities and differences between foreign and domestic VC have gradually become one of the key concerns in the VC field.

Compared to domestic VC, there is a huge difference in the background culture and institutional environment 
between the home countries of foreign VC and Chinese portfolio companies [5]. The lack of geographic proximity between foreign VC and startups may create obstacles to the effective supervision of the portfolio companies [6], while domestic VC and portfolio companies belong to the same country, which is not only geographically close to the portfolio companies but also has a better understanding of the local market conditions and better access to local resources $[7,8]$. Thus, it is natural to ask whether there are systematic differences between foreign and domestic VC in driving CEO replacement. To answer this question, we use a unique hand-collected sample of data from Chinese startups that received VC's support from 1997 to 2017. We find that domestic VC is more likely to make CEO replacement decisions compared to foreign VC. In addition, syndicate with domestic VC increases the likelihood that foreign VC will replace the $\mathrm{CEO}$ of their portfolio companies during the postinvestment management process.

Unlike previous studies, we provide new insights into the study of the relationship between VC and CEO replacement. First, our study contributes to further understanding of the behavioral differences between domestic VC and foreign VC in the postinvestment management process. We extend the existing literature by hypothesizing and empirically demonstrating the impact of VC's background on behavioral differences in the postinvestment management process. We demonstrate that the geographic disadvantage of foreign $\mathrm{VC}$ makes them less likely to engage in postinvestment monitoring and therefore less likely to drive the decision to replace the CEO of their portfolio companies. Second, in terms of research context, previous studies have focused more on VC-backed IPO firms from the United States $[9,10]$, and less attention has been paid to the situation of non-IPO firms, especially Chinese unlisted firms. In addition, not all VCbacked startups can exit successfully, so the results obtained may not apply to non-IPO firms if we focus only on the sample of those that successfully exit by way of IPO. Therefore, in this study, we manually collect data on CEO replacement among startups after receiving VC's support, extend the sample of the study to all startups backed by VC, and empirically verify the impact of investors from different backgrounds on the likelihood of CEO replacement among Chinese startups, which helps direct the focus of existing studies to the issue of CEO replacement among startups in the Chinese context.

\section{Literature Review}

The first person directly associated with VC's key interests is the CEO of the portfolio company. The CEO is considered the most important executive in modern business organizations [11], responsible for articulating the vision and future direction and leading the company's development as the symbolic leader of the organization. Therefore, as the most influential member of the top management team, the CEO replacement is a major corporate event that can impact the well-being of the company [12].

The high level of uncertainty typically faced in investing in startups makes replacing the CEO before a successful IPO a necessity for many startups [10]. First, the CEO of a startup typically has limited resources and context-specific capabilities, making him or her likely to be a good fit for the business at one time but not at another [13]. Second, the market environment faced by public companies is very different and more complex than that faced by startups. As startups grow, can CEOs adapt their competencies to manage an organization that is becoming larger and more complex? Some scholars have expressed doubts about this, including Meyer and Dean (1990) [14], who focused specifically on the possibility of an "executive limit scenario" in which the CEO's management capacity decreases as the firm grows into a large and complex organization, which has since been supported by most scholars [15]. Thus, if necessary, VCs can replace the CEO through the investment contract or by using their power on the board of directors [16]. While replacing the CEO is recognized as a specific action that VCs can take, is associated with reducing uncertainty in the investment process, and is seen by other stakeholders as an important signal of good and positive governance [17], replacing the CEO is, in fact, a cost and risky option, because it is extremely difficult for both academics and boards to predict whether a new CEO will perform well or poorly [18].

Therefore, it is important to examine how VC makes CEO replacement decisions among its portfolio companies, because the replacement of a firm's CEO may be directly related to the future investment returns of the VC. Recent research examines CEO replacement in the context of VC and finds that $\mathrm{CEO}$ replacement in startups occurs more frequently and more quickly when VC at the center of social networks is involved [9], suggesting that the heterogeneity of $\mathrm{VC}$ does have an impact on CEO replacement. Then, when we look at the country heterogeneity of $\mathrm{VC}$, we can find that for those foreign $\mathrm{VC}$ entering the Chinese market, there is an intuitive difference compared to domestic VC; that is, the geographical distance of foreign VC from the portfolio companies is usually much farther than the distance of domestic VC from the portfolio companies, and this difference is naturally formed, is objectively existing, and cannot be changed. Perhaps, foreign VC can shorten their relative distance to their portfolio companies by using the faster and more convenient means of transportation available today (e.g., flights). However, domestic VC can also reduce the relative distance to their portfolio companies with the help of faster and more convenient transportation. Thus, both from physical geography and transportation travel perspective, foreign VC faces more serious geographic distance barriers that will affect CEO replacement in the postinvestment management process.

\section{Hypothesis Development}

Postinvestment monitoring of portfolio company's dynamics is a key component of venture capital in identifying and addressing investment risks. The trust and routine developed through face-to-face communication through onsite visits to companies also help reduce conflict and increase the speed of decision-making. Uzzi (1997) found that firms 
that are familiar with each other can solve problems immediately by better identifying and implementing coordinated solutions [19]. However, the ability of VC to perform in-depth and comprehensive postinvestment monitoring functions is limited by geographic distance, and the greater the geographic distance between the VC and the portfolio company, the higher the cost of travel time and the greater the difficulty of postinvestment monitoring.

Compared with foreign VC, domestic VC is geographically close to its portfolio companies, which makes it easier to have frequent social interactions and to keep track of the development of its portfolio companies [20]; in addition, domestic VC is more likely to transfer experienced partners to the location of its portfolio companies, which are necessary for postinvestment monitoring. But for foreign VC, first, they generally face greater cultural distance from their portfolio companies, which can make effective communication difficult [21]; second, the disadvantage of geographic distance leads to higher oversight costs, which, in particular, can make it more difficult to monitor progress by attending board meetings, providing advice, and supporting the company's ongoing business operations. This may make it more difficult for foreign $\mathrm{VC}$ to assess the capabilities of the $\mathrm{CEO}$, thus creating barriers to effective decision-making; furthermore, despite the availability of easier travel options, cultural, legal, and institutional distance from portfolio companies is not mitigated by the ease of travel. Giroud (2013) and Bernstein et al. (2016) find that travel time between investors and portfolio companies significantly affects investment strategy and performance $[22,23]$. Therefore, we propose the following hypothesis.

Hypothesis 1. Domestic VC is more likely to replace the $\mathrm{CEO}$ of their portfolio companies than foreign VC.

Syndicate with domestic VC is a more common investment approach for foreign $\mathrm{VC}$ to enter the Chinese capital market. From the perspective of foreign VC, including a local partner in the portfolio who is familiar with the investee company helps reduce the degree of information asymmetry caused by cultural differences and geographical distance during the transaction [24]. Through the syndicate, foreign VC not only provides financial support to their portfolio companies together with domestic VC but also jointly performs postinvestment supervision functions. The difficulties caused by the geographical distance barrier to foreign VC are mitigated as the Chinese domestic coinvestment partner assumes part of the postinvestment supervision function and the frequency and intensity of foreign VCs' participation in postinvestment supervision are reduced. Thus, by partnering with VC in the location of the portfolio company, foreign VC can overcome this disadvantage of geographical distance, as the domestic $\mathrm{VC}$ is closer to the portfolio company and can more easily monitor the suitability of the CEO of the portfolio company for the growth of the business. In addition, domestic VC can also frequently interact with other local stakeholders, such as policymakers, financial intermediaries, and other local entrepreneurs, to better understand the domestic market and policy regime [25], which can help foreign VC obtain more information and alleviate information asymmetry, and help make more scientific and rational decisions [26]. Therefore, we propose the following hypothesis.

Hypothesis 2. The syndicate of foreign and domestic $\mathrm{VC}$ is more likely to replace the $\mathrm{CEO}$ of the portfolio companies than foreign VC.

\section{Data Sources and Research Methodology}

4.1. Data. Aizenman and Kendall (2012) find that since 2003, China has become the world's largest net inflow of foreign VCs [27]. Therefore, using China as a sample provides a sample of sufficient size for this paper to study the impact of VC's background on CEO replacement. Regarding the research in this paper, the data used are mainly from the following: (1) the data of Chinese startups backed by VCs from 1997 to 2017 were queried through the Crunchbase database; (2) since the Crunchbase database does not provide the replacement of CEOs of Chinese startups after receiving VC's support, this paper manually searched and matched the CEO replacement of startups after receiving VC's support through the Tianyancha database; (3) the straight-line geographic distance between VCs and their portfolio companies was queried by Amap. After eliminating the missing data in each link, our final dataset contains 7103 year-firm observations invested by 3856 VCs from 1997 to 2017. Excluding missing data for key indicators in each segment, 7103 year-firm observations were obtained.

\subsection{Variables}

4.2.1. Dependent Variable. Referring to Conti and Graham (2020) [9], the likelihood of CEO replacement after a startup receives VC's support is confounded by many factors, and controlling for these factors becomes more difficult when there is a large gap between the time of VC's investment and the time of CEO change. Therefore, to highlight the impact of VC participation on startups, this paper sets the observed period to 1 year after a startup receives VC's support, and the variable takes the value of 1 when the startup's CEO replaces within 1 year after receiving VC's support, and 0 otherwise.

4.2.2. Independent Variable. The Crunchbase database provides the addresses of the $\mathrm{VC}$, so we use the addresses provided by the database to define the $\mathrm{VC}$ as foreign $\mathrm{VC}$ or domestic VC. A venture was identified as a foreign VC when its address was located overseas; otherwise, it was identified as a domestic VC.

4.2.3. Control Variables. Following the existing studies, we have used some factors that may affect CEO replacement as control variables and controlled for the relevant factors at the $\mathrm{VC}$ level and firm level, respectively. The definition of the variables is shown in Table 1 . 
TABLE 1: The definition of the variables.

\begin{tabular}{|c|c|}
\hline Name & Description \\
\hline VC syndicate & The calculation is based on the number of investors participating in the round. \\
\hline VC experience & Calculated as the number of times the VC has invested in other Chinese startups before its involvement in the startup. \\
\hline VC age & The calculation is based on the number of years the VC has been in existence. \\
\hline CEO tenure & The calculation is based on the number of years the CEO has been with the startup. \\
\hline Company age & $\begin{array}{l}\text { Calculated as the number of years between the time the company was founded and the time it received support from } \\
\text { VC. }\end{array}$ \\
\hline $\begin{array}{l}\text { Company } \\
\text { employee }\end{array}$ & $\begin{array}{c}\text { Since the size of startups is usually small, this paper values the variable employee size as } 1 \text { when the size of the company } \\
\text { is greater than or equal to } 50 \text { employees and } 0 \text { otherwise. }\end{array}$ \\
\hline Seed stage & This variable takes the value of 1 if the startup is at the seed stage when it receives VCs' investment and 0 otherwise. \\
\hline Early stage & This variable takes the value of 1 if the startup is at the early stage when it receives VCs' investment and 0 otherwise. \\
\hline Late stage & This variable takes the value of 1 if the startup is at the late stage when it receives VCs' investment and 0 otherwise. \\
\hline VC_Firm distance & $\begin{array}{l}\text { Calculated as a straight-line geographic distance between VC and startups, for which the natural logarithm is taken in } \\
\text { the regression to reduce heteroskedasticity. }\end{array}$ \\
\hline
\end{tabular}

4.3. Research Methodology. In this paper, all the dependent variables of the hypothesis test are binary dummy variables, which essentially belong to the binary discrete choice problem, and the logit regression or probit regression is usually used for estimation. In addition, to ensure the reliability of the regression results, the ordinary least squares (OLS) are added in this study to check the robustness of the results.

$$
\begin{aligned}
\text { CEO replacement }_{i t}= & \alpha_{0}+\alpha_{1}{\text { Domestic } V C_{i t}} \\
& +\sum_{j} \alpha_{j} X_{i t}+\mu_{i t}, \\
\text { CEO replacement } & =\alpha_{0}+\alpha_{1}{\text { Domestic and foreign } V C_{i t}} \\
& +\sum_{j} \alpha_{j} X_{i t}+\mu_{i t} .
\end{aligned}
$$

Equation (1) is used to test hypothesis 1. The sample is composed of domestic VC-backed firms and foreign VCbacked firms. In equation (1), Do mestic $V C_{i t}=1$ denotes domestic VC, and Domestic $V C_{i t}=0$ denotes foreign VC. Equation (2) is used to test Hypothesis 2. The sample consists of companies in which foreign VC invested syndicate with domestic VC and companies in which foreign VC invested. In equation (2), Domestic and foreign $V C_{i t}=1$ denotes syndication of foreign $\mathrm{VC}$ and domestic $\mathrm{VC}$, and Domestic and foreign $V C_{i t}=0$ denotes foreign VC. $X_{i t}$ denotes the control variables. $\mu_{i t}$ denotes the random disturbance term. Since the time of the sample in this paper starts in 1997, time fixed effects are controlled for in the sample to reduce the research error caused by the large period.

\section{Results}

5.1. Descriptive Statistics. Table 2 presents the descriptive statistics for the variables in the sample. As shown in Table 2, the mean value of CEO replacement is 0.097 and the standard deviation of CEO replacement is 0.296 , indicating that the values of CEO replacement are more evenly distributed. Table 3 presents the distribution of startups supported by VC from various backgrounds. As shown in Table 3, 9.97\% of the startups in the sample received investment from foreign $\mathrm{VC}, 73.68 \%$ received investment from domestic VC, and $16.35 \%$ received investment from syndicate of domestic and foreign VC.

5.2. Benchmark Regression Analysis. Table 4 shows results obtained from logit regression, probit regression, and OLS. Columns (1), (3), and (5) are used to test Hypothesis 1. The regression coefficient from columns (1), (3), and (5) is significantly positive and statistically significant, indicating that domestic VC is more likely to be driving CEO replacement in portfolio companies compared to foreign VC. Therefore, Hypothesis 1 is supported. Columns (2), (4), and (6) are used to test Hypothesis 2. The regression coefficient in columns (2), (4), and (6) is significantly positive and statistically significant, indicating that the syndicate of domestic and foreign $\mathrm{VC}$ is more likely to be driving $\mathrm{CEO}$ replacement in portfolio companies than foreign VC. Therefore, Hypothesis 2 is supported.

In terms of control variables, the estimated coefficients of the $\mathrm{VC}$ age, the CEO tenure, and the seed stage are significantly positively related to the CEO replacement, indicating that the older the $\mathrm{VC}$, the longer the CEO's tenure, and the closer to the early stage of the company's development, the more likely it is to replace the CEO. The VC experience and the company age are significantly negatively related to the $\mathrm{CEO}$ replacement. The estimated coefficients of the VC syndicate, the early stage, and late stage are negative, but not significant.

5.3. Robustness Test. Although this paper includes control variables that affect $\mathrm{CEO}$ replacement as much as possible regarding existing studies, even so, there may still be endogeneity problems arising from omitted variables, etc. Given the dependent variable to binary categorical variables in this paper, the standard two-stage estimation approach is not sufficient to address this issue. Therefore, we use the likelihood function of a binary probability model to estimate a model in which both the independent and dependent variables are binary variables. To address possible 
TABle 2: Descriptive statistics of all variables.

\begin{tabular}{|c|c|c|c|c|c|}
\hline Variable & Observations & Mean value & Standard deviation & Minimum value & Maximum value \\
\hline CEO replacement & 7,103 & 0.097 & 0.296 & 0 & 1 \\
\hline Domestic VC & 5,942 & 0.881 & 0.324 & 0 & 1 \\
\hline Domestic and foreign $\mathrm{VC}$ & 1,869 & 0.621 & 0.485 & 0 & 1 \\
\hline VC syndicate & 7,103 & 2.048 & 1.532 & 1 & 22 \\
\hline VC experience & 7,103 & 19.289 & 32.187 & 0 & 324 \\
\hline VC age & 7,103 & 20.792 & 31.880 & 0 & 525 \\
\hline CEO tenure & 7,103 & 3.737 & 4.889 & 0 & 75 \\
\hline Company age & 7,103 & 3.636 & 4.836 & 0 & 75 \\
\hline Company employee & 7,103 & 0.253 & 0.435 & 0 & 1 \\
\hline Seed stage & 7,103 & 0.292 & 0.455 & 0 & 1 \\
\hline Early stage & 7,103 & 0.524 & 0.499 & 0 & 1 \\
\hline Late stage & 7,103 & 0.005 & 0.068 & 0 & 1 \\
\hline VC_Firm distance & 7,103 & 1268.492 & 2696.156 & 0 & 18,715 \\
\hline
\end{tabular}

TABLE 3: Distribution of sample.

\begin{tabular}{lcc}
\hline Variable & Observations & Distribution ratio (\%) \\
\hline Foreign VC & 708 & 9.97 \\
Domestic VC & 5,234 & 73.68 \\
Syndication of domestic and foreign VC & 1,161 & 16.35 \\
Total & 7,103 & 100 \\
\hline
\end{tabular}

TABLE 4: Benchmark regression results.

\begin{tabular}{|c|c|c|c|c|c|c|}
\hline \multirow{2}{*}{ Variable } & \multicolumn{2}{|c|}{ Logit } & \multicolumn{2}{|c|}{ Probit } & \multicolumn{2}{|c|}{ OLS } \\
\hline & $(1)$ & $(2)$ & (3) & $(4)$ & $(5)$ & (6) \\
\hline Domestic VC & $0.710^{* * *}(0.190)$ & & $0.336^{* * *}(0.087)$ & & $0.047^{* * *}(0.011)$ & \\
\hline $\begin{array}{l}\text { Domestic and foreign } \\
\text { VC }\end{array}$ & & $0.419^{*}(0.236)$ & & $0.201^{*}(0.113)$ & & $0.024^{*}(0.015)$ \\
\hline VC syndicate & $-0.003(0.037)$ & $0.060(0.066)$ & $0.000(0.019)$ & $0.029(0.032)$ & $-0.000(0.003)$ & $0.004(0.005)$ \\
\hline VC experience & $-0.067^{*}(0.038)$ & $-0.072(0.088)$ & $-0.037^{*}(0.020)$ & $-0.032(0.042)$ & $-0.006^{*}(0.003)$ & $-0.005(0.006)$ \\
\hline VC age & $0.088^{* *}(0.045)$ & $-0.035(0.116)$ & $0.048^{* *}(0.024)$ & $-0.017(0.055)$ & $0.008^{* *}(0.004)$ & $-0.002(0.007)$ \\
\hline CEO tenure & $0.414^{* * *}(0.058)$ & $0.363^{* * *}(0.077)$ & $0.175^{* * *}(0.028)$ & $0.175^{* * *}(0.040)$ & $0.056^{* * *}(0.009)$ & $0.046^{* * *}(0.012)$ \\
\hline Company age & $\begin{array}{c}-0.414^{* * *} \\
(0.059)\end{array}$ & $\begin{array}{c}-0.362^{* * *} \\
(0.088)\end{array}$ & $\begin{array}{c}-0.173^{* * *} \\
(0.029)\end{array}$ & $\begin{array}{c}-0.171^{* * *} \\
(0.044)\end{array}$ & $\begin{array}{c}-0.056^{* * *} \\
(0.009)\end{array}$ & $\begin{array}{c}-0.046^{* * *} \\
(0.013)\end{array}$ \\
\hline Company employee & $-0.186(0.117)$ & $-0.187(0.195)$ & $-0.089(0.059)$ & $-0.079(0.092)$ & $-0.014(0.009)$ & $-0.010(0.012)$ \\
\hline Seed stage & $0.283^{*}(0.155)$ & $0.367(0.334)$ & $0.135^{*}(0.079)$ & $0.156(0.164)$ & $0.027^{* *}(0.013)$ & $0.025(0.025)$ \\
\hline Early stage & $-0.034(0.145)$ & $-0.043(0.223)$ & $-0.025(0.073)$ & $-0.048(0.103)$ & $-0.003(0.011)$ & $-0.005(0.013)$ \\
\hline Late stage & $-1.007(1.832)$ & $0.626(0.640)$ & $-0.302(0.581)$ & $0.244(0.334)$ & $-0.045(0.062)$ & $0.042(0.062)$ \\
\hline Constant & $\begin{array}{c}-3.056^{* * *} \\
(0.240)\end{array}$ & $\begin{array}{c}-2.782^{* * *} \\
(0.377)\end{array}$ & $\begin{array}{c}-1.681^{* * *} \\
(0.114)\end{array}$ & $\begin{array}{c}-1.564^{* * *} \\
(0.177)\end{array}$ & $0.042^{* * *}(0.016)$ & $0.063^{* * *}(0.023)$ \\
\hline Year & YES & YES & YES & YES & YES & YES \\
\hline Observations & 5942 & 1869 & 5942 & 1869 & 5942 & 1869 \\
\hline$R^{2}$ & 0.046 & 0.049 & 0.038 & 0.045 & 0.039 & 0.040 \\
\hline
\end{tabular}

Notes: standard errors are provided in parentheses. ${ }^{*} p<0.1,{ }^{* *} p<0.05$, and ${ }^{* * *} p<0.01$.

endogeneity issues, we use the air quality in the area where the startup is located as our instrumental variable, and the air quality is measured as the annual average PM2.5 concentration in the area where the startup is located. The rationality of this approach is that referring to Huang et al. (2020) [28], air pollution makes investors more prone to investment bias, which implies that the air quality in the area where the startup is located affects investors' behavioral decisions, which ensures that the instrumental variable of air quality is more correlated with the dependent variable; however, air quality does not directly affect the decision of CEO replacement, which ensures the exogeneity of the instrumental variable.

As shown in Table 5, columns (1) and (3) report the regression results of the instrumental variables and independent variables in the first stage, and it can be found that the estimated coefficients are significantly positive, indicating that the instrumental variables are highly correlated with the independent variables, while the F-statistics of the regression results are 255.230 and 251.980, respectively, 
TABLE 5: Estimation results of two-stage instrumental variables.

\begin{tabular}{|c|c|c|c|c|}
\hline Variable & $\begin{array}{l}\text { First stage } \\
\text { (1) }\end{array}$ & $\begin{array}{c}\text { Second stage } \\
\text { (2) }\end{array}$ & $\begin{array}{c}\text { First stage } \\
\text { (3) }\end{array}$ & $\begin{array}{c}\text { Second stage } \\
\text { (4) }\end{array}$ \\
\hline Air quality & $-0.038^{* * *}(0.001)$ & & $-0.073^{* * *}(0.002)$ & \\
\hline Domestic VC & & $0.302^{*}(0.178)$ & & \\
\hline Domestic and foreign VC & & & & $0.397^{* *}(0.181)$ \\
\hline VC syndicate & $0.015^{* * *}(0.003)$ & $0.002(0.021)$ & $0.054^{* * *}(0.005)$ & $0.002(0.037)$ \\
\hline VC experience & $-0.003(0.003)$ & $-0.037^{*}(0.019)$ & $0.034^{* * *}(0.007)$ & $-0.040(0.041)$ \\
\hline $\mathrm{VC}$ age & $-0.050^{* * *}(0.004)$ & $0.046^{*}(0.026)$ & $0.013(0.009)$ & $-0.017(0.056)$ \\
\hline CEO tenure & $-0.005(0.004)$ & $0.174^{* * *}(0.017)$ & $-0.012 *(0.007)$ & $0.176^{* * *}(0.030)$ \\
\hline Company age & $0.007^{* *}(0.004)$ & $-0.173^{* * *}(0.018)$ & $0.011(0.007)$ & $-0.172^{* * *}(0.032)$ \\
\hline Company employee & $-0.061^{* * *}(0.009)$ & $-0.091(0.059)$ & $0.002(0.015)$ & $-0.072(0.096)$ \\
\hline Seed stage & $0.141^{* * *}(0.012)$ & $0.142^{*}(0.084)$ & $0.096^{* * *}(0.029)$ & $0.113(0.168)$ \\
\hline Early stage & $0.113^{* * *}(0.011)$ & $-0.020(0.075)$ & $0.074^{* * *}(0.017)$ & $-0.075(0.106)$ \\
\hline Late stage & $-0.130^{*}(0.067)$ & $-0.309(0.520)$ & $0.034(0.065)$ & $0.237(0.351)$ \\
\hline Constant & $1.021^{* * *}(0.014)$ & $-1.654^{* * *}(0.168)$ & $0.664^{* * *}(0.035)$ & $-1.575^{* * *}(0.183)$ \\
\hline Year & YES & YES & YES & YES \\
\hline Observations & 5942 & 5942 & 1869 & 1869 \\
\hline Adj $R$-squared & 0.300 & & 0.573 & \\
\hline$F$ & 255.230 & & 251.980 & \\
\hline
\end{tabular}

Notes: standard errors are provided in parentheses. ${ }^{*} p<0.1,{ }^{* *} p<0.05$, and ${ }^{* * *} p<0.01$.

which are much larger than the criteria for determining weak instrumental variables 10 , further indicating that there is no weak instrumental variable problem. Columns (2) and (4) report the regression results of the second stage, and it can be found that the estimated coefficients are significantly positive, which is consistent with the basic estimation results. Therefore, the use of two-stage instrumental variable estimation indicates the robustness of the results of the benchmark regression.

5.4. Heterogeneity Analysis. The most prominent feature of China's geographical location is its vast geography. Therefore, even within a country, the geographical distance between north and south, and east and west is also a problem for both VC and startups, and they must be aware of this. In the sample used in our study, the geographic distance between the VC from Shenzhen and the startups from Urumqi is about 3385.01 kilometers, the geographic distance between the VC from Hong Kong and the startups from Shenzhen is about 31.50 kilometers, the geographic distance between the VC from Tokyo to the startups from Changchun is about 1527 kilometers, and the geographic distance between the VC from New York and the startup from Beijing is about 10803 kilometers. These four samples suggest that (1) even within China, there are cases where the $\mathrm{VC}$ is closer or farther away from the portfolio company, and (2) even for crossborder investments, there are likewise cases where the VC is closer or farther away from the portfolio company. Therefore, to further verify the effect of geographical distance on the relationship between $\mathrm{VC}$ and CEO replacement, we further divide the sample of domestic $\mathrm{VC}$ and foreign $\mathrm{VC}$ according to the geographic distance between the $\mathrm{VC}$ and the portfolio company. According to the distribution of geographic distances between VC and startups in the sample, for domestic VC, when the geographic distance is greater than or equal to
1500 kilometers, the VC is considered geographically distant from the portfolio company, and when the geographic distance is less than 1500 kilometers, the VC is considered geographically proximate to the portfolio company. For foreign VC, when the geographical distance is greater than 3000 kilometers, it is considered that the VC is geographically distant from the portfolio company, and when the geographical distance is less than or equal to 3000 kilometers, it is considered that the VC is geographically proximate to the portfolio company.

As shown in Table 6, columns (1), (3), and (5) present the estimation results for domestic VC geographically proximate to the portfolio company and foreign $\mathrm{VC}$ geographically distant from the portfolio company. The regression coefficient from columns (1), (3), and (5) is significantly positive and statistically significant, which is consistent with the previous benchmark regression results, indicating that there is a greater difference between domestic and foreign $\mathrm{VC}$ in replacing the CEOs of their portfolio companies, specifically when the $\mathrm{VC}$ is closer to the geographic distance of the portfolio company, the greater the possibility of replacing the CEO. Columns (2), (4), and (6) present the results of domestic VC geographically distant portfolio companies compared to foreign VC geographically proximate portfolio companies. The regression coefficients from columns (2), (4), and (6) are insignificant and not statistically significant, indicating that there is no significant difference between VC from different backgrounds in terms of the likelihood of replacing the CEO of the portfolio company when the $\mathrm{VC}$ is geographically proximate to the portfolio company. Therefore, through the analysis of heterogeneity, we further find that the likelihood of CEO replacement is lower when the geographic distance between the VC and the portfolio company is farther, and the likelihood of CEO replacement is higher when the geographic distance between the VC and the portfolio company is closer. 
TABLE 6: Regression results of heterogeneity analysis.

\begin{tabular}{|c|c|c|c|c|c|c|}
\hline \multirow{2}{*}{ Variable } & \multicolumn{2}{|c|}{ Logit } & \multicolumn{2}{|c|}{ Probit } & \multicolumn{2}{|c|}{ OLS } \\
\hline & (1) & (2) & (3) & $(4)$ & (5) & (6) \\
\hline Domestic VC & $0.819^{* * *}(0.219)$ & $0.389(0.399)$ & $0.382^{* * *}(0.100)$ & $0.262(0.197)$ & $0.053^{* * *}(0.012)$ & $0.036(0.030)$ \\
\hline VC syndicate & $-0.014(0.038)$ & $0.204(0.179)$ & $-0.006(0.020)$ & $0.127(0.097)$ & $-0.001(0.003)$ & $0.025(0.018)$ \\
\hline VC experience & $-0.060(0.040)$ & $-0.108(0.135)$ & $-0.033(0.021)$ & $-0.072(0.066)$ & $-0.006(0.004)$ & $-0.011(0.012)$ \\
\hline $\mathrm{VC}$ age & $0.119^{* *}(0.048)$ & $-0.061(0.134)$ & $0.064^{* *}(0.025)$ & $-0.035(0.070)$ & $0.011^{* *}(0.004)$ & $-0.006(0.012)$ \\
\hline CEO tenure & $0.362^{* * *}(0.064)$ & $0.700^{* * *}(0.183)$ & $0.149^{* * *}(0.031)$ & $0.317^{* * *}(0.071)$ & $0.047^{* * *}(0.010)$ & $0.101^{* * *}(0.017)$ \\
\hline Company age & $-0.362^{* * *}(0.066)$ & $-0.715^{* * *}(0.202)$ & $-0.147^{* * *}(0.032)$ & $-0.316^{* * *}(0.078)$ & $-0.046^{* * *}(0.010)$ & $-0.102^{* * *}(0.018)$ \\
\hline Company employee & $-0.100(0.123)$ & $-0.776^{*}(0.418)$ & $-0.049(0.062)$ & $-0.321^{*}(0.189)$ & $-0.007(0.010)$ & $-0.053^{* *}(0.025)$ \\
\hline Seed stage & $0.234(0.163)$ & $0.632(0.492)$ & $0.107(0.083)$ & $0.410 *(0.244)$ & $0.022(0.014)$ & $0.074^{*}(0.041)$ \\
\hline Early stage & $-0.072(0.154)$ & $0.187(0.416)$ & $-0.046(0.077)$ & $0.153(0.204)$ & $-0.006(0.012)$ & $0.017(0.026)$ \\
\hline Late stage & $-0.689(1.806)$ & $-10.636^{* * *}(0.639)$ & $-0.159(0.611)$ & $0.000(0.002)$ & $-0.034(0.086)$ & $-0.022(0.025)$ \\
\hline Constant & $-3.214^{* * *}(0.271)$ & $-2.713^{* * *}(0.577)$ & $-1.752^{* * *}(0.128)$ & $-1.649^{* * *}(0.301)$ & $0.032^{*}(0.017)$ & $0.054(0.045)$ \\
\hline Year & YES & YES & YES & YES & YES & YES \\
\hline Observations & 5270 & 672 & 5270 & 672 & 5270 & 672 \\
\hline$R^{2}$ & 0.035 & 0.166 & 0.028 & 0.147 & 0.027 & 0.162 \\
\hline
\end{tabular}

Notes: standard errors are provided in parentheses. ${ }^{*} p<0.1,{ }^{* *} p<0.05$, and ${ }^{* * *} p<0.01$.

\section{Discussion and Conclusion}

6.1. Conclusion. This paper explores the impact and theoretical mechanisms of VC's background on CEO replacement in portfolio companies, using a sample of VC-backed Chinese startups from 1997 to 2017 as a research sample. We obtain the following three conclusions.

(1) Compared to domestic VC, the geographical distance between foreign $\mathrm{VC}$ and Chinese startups makes it more difficult to monitor the development of the firm after the investment, and therefore, domestic VC is more likely to change the CEO of the firm compared to foreign VC.

(2) When foreign VC enters the Chinese market for development, by investing in Chinese startups in cooperation with domestic VC, domestic VC as a coinvestor can effectively monitor and advise the portfolio company, and the geographical proximity disadvantage of foreign $\mathrm{VC}$ and the portfolio company can be supplemented by local coinvestors, increasing the possibility of changing the CEO in the postinvestment management process.

(3) There is no significant difference in CEO replacement when VC with different backgrounds is close to the distance of the portfolio company. When the distance of VC from different backgrounds to the portfolio company differs significantly, there is a significant difference in CEO replacement, specifically: the farther the geographical distance between VC and the portfolio company, the smaller the possibility of CEO replacement.

The findings of this study provide a better understanding of the relationship between the background of $\mathrm{VC}$ and $\mathrm{CEO}$ replacement of the portfolio company, who is the decisionmaker and executor of the company's business decisions and the "helmsman" of the company's operation and management, and therefore, the CEO replacement can have a significant impact on both the VC and the company itself. Since the information of a startup is usually nonpublic, VC faces a large information asymmetry in understanding whether the CEO of a startup is suitable for the current development of the company, which leads to a huge risk of investment projects. Therefore, the geographical proximity effect shown by VC in its selection of investment projects increases the supervision and management of the portfolio company and reduces the investment risk.

6.2. Theoretical Contribution. This study makes important contributions to the VC literature. First, although previous studies in the literature have focused on CEO replacement in VC-backed firms, their research samples have mostly focused on IPO firms, especially in developed countries, and little is known about CEO replacement in developing countries, especially in the context of China, which has the second-largest VC market in the world. Therefore, this paper focuses on VC-backed Chinese startups to explore the key issue of CEO replacement. Second, it is the first study to compare the behavioral differences between domestic and foreign VC in the postinvestment management process. Third, it provides evidence on the benefits of foreign VC entering the Chinese market in syndication with domestic $\mathrm{VC}$ from the perspective of CEO replacement. Fourth, this study suggests that the geographic proximity of VC to portfolio companies is an important mechanism influencing the decision to make a CEO replacement.

6.3. Limitations and Future Research. This study has some limitations that provide opportunities for future research. First, the study focuses only on VC-backed Chinese startups; therefore, whether the behavioral decision to replace the CEO of a foreign startup is significantly different when Chinese and foreign VC participate in offshore investments is unknown and needs further study. Second, although the research explores the impact of the background of $\mathrm{VC}$ on CEO replacement, it does not further explore the characteristics of those CEOs who are replaced due to the 
availability of data. Therefore, future research plans to shift theoretical and practical attention from "who is more likely to replace CEO" to "what type of CEO is more likely to be replaced." In addition, existing research suggests that replacing the $\mathrm{CEO}$ is a cost and risky choice, so future research will focus on whether replacing the $\mathrm{CEO}$ of a portfolio company affects the investment performance of $\mathrm{VC}$ and the development of startups.

\section{Data Availability}

The data used to support the findings of this study are available from the corresponding author upon request.

\section{Conflicts of Interest}

The authors declare that they have no conflicts of interest.

\section{Acknowledgments}

This work was supported by grants from the National Natural Science Foundation of China (Nos. 72072105 and 71962033).

\section{References}

[1] D. Lucquin, "Investisseur en capital risque en biotechnologies," Les Tribunes de la santé, vol. 10, no. 1, pp. 59-65, 2006.

[2] N. Wasserman, "Founder-CEO succession and the paradox of entrepreneurial success," Organization Science, vol. 14, no. 2, pp. 149-172, 2003.

[3] V. Gerasymenko and J. D. Arthurs, "New insights into venture capitalists' activity: IPO and time-to-exit forecast as antecedents of their post-investment involvement," Journal of Business Venturing, vol. 29, no. 3, pp. 405-420, 2014.

[4] M. Ewens and M. Marx, "Founder replacement and startup performance," Review of Financial Studies, vol. 31, no. 4, pp. 1532-1565, 2018.

[5] Y. Li, I. B. Vertinsky, and J. Li, "National distances, international experience, and venture capital investment performance," Journal of Business Venturing, vol. 29, no. 4, pp. 471-489, 2014.

[6] T. J. Chemmanur, T. J. Hull, and K. Krishnan, "Do local and international venture capitalists play well together? The complementarity of local and international venture capitalists," Journal of Business Venturing, vol. 31, no. 5, pp. 573-594, 2016.

[7] M. M. Mäkelä and M. V. Maula, "Interorganizational commitment in syndicated cross-border venture capital investments," Entrepreneurship: Theory and Practice, vol. 30, no. 2, pp. 273-298, 2006.

[8] J. Que and X. Zhang, "The role of foreign and domestic venture capital in innovation: evidence from China," $A c$ counting and Finance, vol. 60, no. S1, pp. 1077-1110, 2020.

[9] A. Conti and S. J. H. Graham, "Valuable choices: prominent venture capitalists' influence on startup CEO replacements," Management Science, vol. 66, no. 3, pp. 1325-1350, 2020.

[10] S. Chahine and Y. Zhang, "Change gears before speeding up: the roles of Chief Executive Officer human capital and venture capitalist monitoring in Chief Executive Officer change before initial public offering," Strategic Management Journal, vol. 41, no. 9, pp. 1653-1681, 2020.
[11] M. Abebe and D. Anthony Alvarado, "Founder-CEO status and firm performance: an exploratory study of alternative perspectives," Journal of Strategy and Management, vol. 6, no. 4, pp. 343-357, 2013.

[12] N. Kavadis, M. L. Heyden, and J. S. Sidhu, "Fresh in the saddle: the influence of a new CEO's vision and origin, and CEO succession type on market actors' reactions," Long Range Planning, Article ID 102050, 2020.

[13] G. Chen and D. C. Hambrick, "CEO replacement in turnaround situations: executive (Mis)Fit and its performance implications," Organization Science, vol. 23, no. 1, pp. 225-243, 2012.

[14] G. D. Meyer and T. J. Dean, “An upper echelons perspective on transformational leadership problems in high technology firms," The Journal of High Technology Management Research, vol. 1, no. 2, pp. 223-242, 1990.

[15] H. Hoang and J. Gimeno, "Becoming a founder: how founder role identity affects entrepreneurial transitions and persistence in founding," Journal of Business Venturing, vol. 25, no. 1 , pp. 41-53, 2010.

[16] D. J. Cumming and J. G. MacIntosh, "A cross-country comparison of full and partial venture capital exits," Journal of Banking \& Finance, vol. 27, no. 3, pp. 511-548, 2003.

[17] W. Shen and A. A. Cannella, "Revisiting the performance consequences of CEO succession: the impacts of successor type, postsuccession senior executive turnover, and departing CEO tenure," Academy of Management Journal, vol. 45, no. 4, pp. 717-733, 2002.

[18] T. J. Quigley, D. C. Hambrick, V. F. Misangyi, and G. A. Rizzi, "CEO selection as risk-taking: a new vantage on the debate about the consequences of insiders versus outsiders," Strategic Management Journal, vol. 40, no. 9, pp. 1453-1470, 2019.

[19] B. Uzzi, "Social structure and competition in interfirm networks: the paradox of embeddedness," Administrative Science Quarterly, vol. 42, no. 1, pp. 35-67, 1997.

[20] D. De Clercq, V. H. Fried, O. Lehtonen, and H. J. Sapienza, "An entrepreneur's guide to the venture capital galaxy," Academy of Management Perspectives, vol. 20, no. 3, pp. 90112, 2006.

[21] L. Guiso, P. Sapienza, and L. Zingales, "Trusting the stock market," The Journal of Finance, vol. 63, no. 6, pp. 2557-2600, 2008.

[22] X. Giroud, "Proximity and investment: evidence from plantlevel data," Quarterly Journal of Economics, vol. 128, no. 2, pp. 861-915, 2013.

[23] S. Bernstein, X. Giroud, and R. R. Townsend, "The impact of venture capital monitoring," The Journal of Finance, vol. 71, no. 4, pp. 1591-1622, 2016.

[24] D. Cumming and N. Dai, "Local bias in venture capital investments," Journal of Empirical Finance, vol. 17, no. 3, pp. 362-380, 2010.

[25] M. M. Mäkelä and M. V. Maula, "Attracting cross-border venture capital: the role of a local investor," Entrepreneurship \& Regional Development, vol. 20, no. 3, pp. 237-257, 2008.

[26] H. Jenner and J. A. Suchard, "Foreign VCs and venture success: evidence from China," Journal of Corporate Finance, vol. 21, pp. 16-35, 2013.

[27] J. Aizenman and J. Kendall, "The internationalization of venture capital," Journal of Economics Studies, vol. 39, no. 5, pp. $488-511,2012$.

[28] J. Huang, N. Xu, and H. Yu, "Pollution and performance: do investors make worse trades on hazy days?" Management Science, vol. 66, no. 10, pp. 4455-4476, 2020. 